\title{
iDeal Mobile Food and Beverage Platform
}

\author{
Hengki Sulaiman \\ Master of Management at Bakrie University, Epicentrum Kuningan, South Jakarta
}

\section{Article Info \\ Volume 8, Issue 3 \\ Page Number : 836-846}

\section{Publication Issue}

May-June-2021

\section{Article History}

Accepted : 10 June 2021

Published : 20 June 2021

\section{ABSTRACT}

The development of mobile payment in the country is significant each year, has become a trend and lifestyle among the people with a user level reaching $70 \%$ by the younger population and $67 \%$ by rising digital usage. One of the mobile payment service users that is widely used after transportation is as a means of payment for food delivery and on site dining. From the 2018 Nielsen Survey results, 41\% of consumers claimed to have used food delivery services. Based on the JakPat Survey that $36.9 \%$ of consumers use mobile payment services for on site dining. Seeing the great opportunities and problems that are often repeated experienced by food \& beverage businesses, with the Ideal payment platform, a new innovation business model that can overcome the problems that are often experienced by food \& beverage businesses. Ideal Payment is a mobile digital platform application engaged in food \& beverage that connects customers and merchants in making ordering and payment transactions using a mobile smartphone without going through the cashier, Ideal payment platform that is equipped with ordering features such as (pickup, pre order and pay at table ) and can help improve the productivity of queue management and customer engagement management. The ideal payment platform can be used in various business types such as (restaurants, fast food, food court, dessert \& cakes and coffee shops). The feasibility of the Ideal payment platform business model shows that this business model can be run based on the NPV results with a positive value of NPV >0 which is Rp. 9,162,356,129. Keywords: Mobile payment, food \& beverage platform, business plan, Business model canvas, value proposition.

\section{INTRODUCTION}

The development of technology and information and communication has penetrated into various aspects of life in the digital age, one of which is the application of information technology in the field of food \& Beverage platforms and mobile payments. The rapid development of technology has resulted in one of which is the emergence of new technologies that are more innovative that can encourage entrepreneurs 
and startups to develop new products and services related to the industry. According to a Federal Reserve study (2016), with the rapid development of smartphones, mobile payments are becoming more and more popular among consumers and are gradually changing non-cash trade around the world. According to the People's Bank of China, the number of mobile transactions in the US reached 1.3 billion in 2015, contributing 5. 6\% (percent) of total non-cash payment transactions, in some countries, such as China, mobile payment has become a bank card balance. Mobile transactions have exceeded the total transactions made by physical bank cards by $43 \%$ (percent). In addition to the number of transactions, the number of different mobile payment users is also increasing rapidly.

Mobile paymentis a non-cash transaction or can also be called a payment system using a mobile telephone device for the needs of shopping for goods and services supported by applications that act as cell phone purses. So far, mobile payment services have been adopted by quick service-oriented industries such as public transportation, service stations, retail, fast food, food delivery and e-commerce. Wider adoption has not been as fast or as wide as expected. (Holmes et al, 2014). The development of the mobile payment system has significantly evolved to provide new opportunities for food \& beverage businesses and customers in providing more personalized service values, because it can enhance and deepen relationships with existing customers and is also a major reason for attracting new customers. The mobile payment system also has the potential to overcome problems that are often experienced by food \& beverage business practitioners, because so far the mobile payment system specifically for food \& beverage is still not integrated with the mobile point of sales (mPOS) application system so that customers when making transactions are still through cashiers and manual recording done by waiters. Currently the mobile food \& beverage system is still not available in the country, except for mobile payment applications that are still utilized by food delivery players such as GO FOOD and GRAB FOOD. Beverage which is not yet integrated with the mobile point of sales (mPOS) application system so that customers when conducting transactions are still through cashiers and manual recording is done by waiters. Currently the mobile food \& beverage system is still not available in the country, except for mobile payment applications that are still utilized by food delivery players such as GOFOOD and GRAB FOOD. beverage which is not yet integrated with the mobile point of sales (mPOS) application system so that customers when conducting transactions are still through cashiers and manual recording is done by waiters. Currently the mobile food \& beverage system is still not available in the country, except for mobile payment applications that are still utilized by food delivery players such as GOFOOD and GRAB FOOD.

\section{PRODUCT ASPECT OF TECHNOLOGY INNOVATION}

\section{A. PRODUCT DESCRIPTION OF INNOVATION}

iDEAL platform a new innovation business model that can overcome the problems that are often experienced by food \& beverage businesses. iDEAL platform is a mobile digital platform application engaged in food \& beverage that connects customers and merchants to make ordering and payment transactions using a mobile smartphone without going through the cashier.

\section{B. PRODUCT DEVELOPMENT BACKGROUND}

The development of mobile payment as a payment tool for digital transactions with increasingly varied services such as online transportation services, food delivery, on site dining, e-commerce and so on. That the mobile payment service system for on site dining payments still has several obstacles that are often experienced by customers despite using a digital wallet as a means of payment. As for the problems 
that are often experienced by customers such as timeconsuming queuing, unable to service when the customer is crowded, the impractical ordering system still uses the recording and the level of customer engagement that has not been digitally implemented by food \& beverage businesses. iDEAL platform is able to drive new innovations and can be a solution for food \& business

\section{PRODUCT UPDATES}

IDEAL business planning platform that was developed as a new innovation in a mobile payment food \& beverage system that is integrated with a mobile point of sales (mPOS) system to be able to service online booking and payment transactions using mobile applications with the advantageous features offered are order management such as (pickup orders, pre orders and pay at tables), customer engagement, search stores by utilizing GPS location and display more user friendly. The current mPOS system is still limited to the scope of operational activities of outlets that previously used the old model cashier application, whose function was limited to recording transactions, the development of the mPOS application now uses mobile for easy transaction recording, reporting, payment integrated with mobile digital, but in this case overcoming the problem of queuing, customer enggament is still not well coordinated still experiencing some obstacles such as having to add devices, adding tablespoons to overcome the queue but this is still not effective and efficient. Then there are still many queues when in the process of making an order / payment through the cashier and the process of inputting orders by waiters are also still using the manual system and consuming a lot of human resources that should be even more efficient for operational costs. When exploring this issue deeper, that the application that is available on the market there is a major difficulty is that the application is still not enough to support the productivity of the ongoing business there are still some obstacles. customer enggament is still not well coordinated still experiencing some obstacles such as having to add devices, adding tablespoons to overcome the queue but this is still not effective and efficient. Then there are still many queues when in the process of making an order / payment through the cashier and the process of inputting orders by waiters also still using the manual system and consuming a lot of human resources that should be even more efficient for operational costs. When exploring this issue deeper, that the application that is available on the market there is a major difficulty is that the application is still not enough to support the productivity of the ongoing business there are still some obstacles. Customer enggament is still not well coordinated still experiencing some obstacles such as having to add devices, adding tablespoons to overcome the queue but this is still not effective and efficient. Then there are still many queues when in the process of making an order / payment through the cashier and the process of inputting orders by waiters are also still using the manual system and consuming a lot of human resources that should be even more efficient for operational costs. When exploring this issue deeper, that the application that is available on the market there is a major difficulty is that the application is still not enough to support the productivity of the ongoing business there are still some obstacles. addition of tablespoons to overcome the queue but this is still not effective and efficient. Then there are still many queues when in the process of making an order / payment through the cashier and the process of inputting orders by waiters are also still using the manual system and consuming a lot of human resources that should be even more efficient for operational costs. When exploring this issue deeper, that the application that is available on the market there is a major difficulty is that the application is still not enough to support the productivity of the ongoing business there are still some obstacles. Addition of tablespoons to overcome the queue but this is still not effective and efficient. Then there are still many queues when in the process 
of making an order / payment through the cashier and the process of inputting orders by waiters also still using the manual system and consuming a lot of human resources that should be even more efficient for operational costs. When exploring this issue deeper, that the application that is available on the market there is a major difficulty is that the application is still not enough to support the productivity of the ongoing business there are still some obstacles. Then there are still many queues when in the process of making an order / payment through the cashier and the process of inputting orders by waiters also still using the manual system and consuming a lot of human resources that should be even more efficient for operational costs. When exploring this issue deeper, that the application that is available on the market there is a major difficulty is that the application is still not enough to support the productivity of the ongoing business there are still some obstacles. Then there are still many queues when in the process of making an order / payment through the cashier and the process of inputting orders by waiters are also still using the manual system and consuming a lot of human resources that should be even more efficient for operational costs. When exploring this issue deeper, that the application that is available on the market there is a major difficulty is that the application is still not enough to support the productivity of the ongoing business there are still some obstacles.

\section{MARKET BUSINESS ANALYSIS}

The results of market business analysis using the Town Matrix method. The Tows Matrix, developed by Weihrich (1982), is used to analyze the external and internal environments to describe grand strategies and visions. Tows matrix helps identify systematic relationships between threats, opportunities, weaknesses and strengths, and offers a structure for generating strategies based on those relationships. (Weihrich, 1982). The following is the formulation of the results from Porter's Five Forces and PEST external environment analysis.

Table 1.1 Town Matrix Analysis iDeal Platform

\begin{tabular}{|c|c|c|}
\hline $\begin{array}{l}\text { Internal Factors / } \\
\text { External Factors }\end{array}$ & $\begin{array}{l}\text { Stretchers (S) } \\
\text { 1. Offering an order management } \\
\text { service so customers can place an } \\
\text { order before coming to the location, } \\
\text { the point of sales application will } \\
\text { automatically inform when the order } \\
\text { is completc. } \\
2 \text {. Offering services to facilitate } \\
\text { orders and payments more quickly } \\
\text { and is integrated with the point of } \\
\text { sales system. }\end{array}$ & $\begin{array}{l}\text { Weaknesses (W) } \\
\text { 1. The development of digital } \\
\text { payment food \& beverage } \\
\text { technology that has not been } \\
\text { integrated } \\
\text { 2. Competitive rivalry is very high }\end{array}$ \\
\hline $\begin{array}{l}\text { Opportumities }(\mathrm{O}) \\
\text { 1. Mobilc Payment has } \\
\text { become a lifestyle among } \\
\text { the people } \\
\text { 2. } 68 \% \text { rising digital usage }\end{array}$ & $\begin{array}{l}\text { SO strategies } \\
\text { 1. Focus on developing and putting } \\
\text { forward order management scrvice } \\
\text { features that are integrated and easy } \\
\text { to usc, so customers without the } \\
\text { need to queue to the cashicr. } \\
\text { 2. Focus on developing and } \\
\text { prioritizing user friendly service } \\
\text { features in increasing engagement } \\
\text { between customers and merchants. }\end{array}$ & $\begin{array}{l}\text { WO strategies } \\
\text { 1. Create an app checkout system } \\
\text { and utilize the GPS feature on their } \\
\text { phone to be integrated with the } \\
\text { merchant's point of sales } \\
\text { application. } \\
\text { 2. Focus on developing value added } \\
\text { service and customer experience. }\end{array}$ \\
\hline $\begin{array}{l}\text { Threat (T) } \\
\text { 1. Cyber } \\
\text { 2. New type of fraud } \\
\text { 3. } 76 \% \text { of cash users are } \\
\text { quite high among the } \\
\text { people } \\
\text { 4. Unfair business } \\
\text { competition }\end{array}$ & $\begin{array}{l}\text { ST strategies } \\
\text { 1. Optimizing risk management by } \\
\text { utilizing government support and } \\
\text { improving the cyber risk security } \\
\text { system } \\
\text { 2. Increase comfort, safety and } \\
\text { cxpand service adcquacy. }\end{array}$ & $\begin{array}{l}\text { WT strategies } \\
\text { 1. Strengthening the security system } \\
\text { and the reliability of the } \\
\text { infrastructure system as well as legal } \\
\text { and legal aspects of supervision } \\
\text { 2. Broadening the scope of services } \\
\text { and awareness of target customers. } \\
\text { 3. Focus on customer centric }\end{array}$ \\
\hline
\end{tabular}

\section{E. PRODUCT ADVANTAGES AND WEAKNESSES}

The competition for mobile payments is increasing in Indonesia. The players are increasingly aggressive in acquiring customers, with various promotional strategies being carried out. Mobile payment players continue to aggressively offer a variety of convenience and collaboration services with various parties to optimize the use of digital wallets. The following are the results of the analysis of several indirect competitors.

Table 1.2 Competitor Analysis

\begin{tabular}{|l|c|c|c|c|cc}
\hline & IDEAL & $\begin{array}{c}\text { GRAB } \\
\text { FOOD }\end{array}$ & $\begin{array}{c}\text { GO } \\
\text { FOOD }\end{array}$ & OVO & FLXD & $\begin{array}{c}\text { AJA } \\
\text { LINK }\end{array}$ \\
\hline $\begin{array}{l}\text { Food Delivery } \\
\text { Service }\end{array}$ & - & $\checkmark$ & $\checkmark$ & - & - & - \\
\hline $\begin{array}{l}\text { Pick up } \\
\text { Pay at Tablc }\end{array}$ & $\checkmark$ & - & $\checkmark$ & - & - & - \\
\hline $\begin{array}{l}\text { Pay at Cashicr (Scan } \\
\text { Barcode) }\end{array}$ & - & $\checkmark$ & $\checkmark$ & $\checkmark$ & $\checkmark$ & $\checkmark$ \\
\hline $\begin{array}{l}\text { Booking \& } \\
\text { Reservations }\end{array}$ & $\checkmark$ & - & - & - & - & - \\
\hline $\begin{array}{l}\text { Customer } \\
\text { Engagement } \\
\text { Merchant }\end{array}$ & $\checkmark$ & - & - & - & - & - \\
\hline Scarch Storc & $\checkmark$ & $\checkmark$ & $\checkmark$ & - & - & - \\
\hline $\begin{array}{l}\text { Reccivc and alcrt at } \\
\text { cashicr }\end{array}$ & $\checkmark$ & - & - & - & - & - \\
\hline Checkout $\Lambda$ pp & $\checkmark$ & $\checkmark$ & $\checkmark$ & - & - & - \\
\hline QRIS Code & $\checkmark$ & $\checkmark$ & $\checkmark$ & $\checkmark$ & $\checkmark$ & $\checkmark$ \\
\hline
\end{tabular}




\section{MARKET POTENTIAL ASPECTS}

\section{A. MARKET TARGET AND MARKET POTENTIAL}

Based on Cekindo data on web pages https://www.cekindo.com/sectors/food- beverages, Indonesia, with the third fastest growing economy in the group of twenty (G20), the two substantive markets and attracting a very dynamic and highly demanded food \& beverage market. Food \& beverage in Indonesian companies that produce value added products. The growth of the food \& beverage sector is supported by the basic needs of people to eat and drink, increased income and increased food expenditure by the middle class, consequently this is a relatively safe investment choice for some investors. The iDEAL platform target market uses a selective specialization pattern, which targets cashless society, with an age range of $\leq 20 \rightarrow 35$ years, with social middle class up to level, where the average expenditure is Rp. 200,000 to> Rp. 500, 000 per month is the top user of the mobile platform for almost every financial transaction using digital via smartphone. (Jakpat Report, 2017).

The Indonesian Ministry estimates that, in 2018, the food \& beverage sector will grow by $6.7 \%$ in total to IDR 63.25 trillion (USD 4.6 billion). Based on Google trend data (2019), $1.8 \mathrm{x}$ year on year the growth of topics related to food \& beverage is increasing in the google search tool. Based on MDI Ventures \& Mandiri Securities research (2018). That the use of mobile payment services in Indonesia is more dominated by the food $\&$ beverage service sector and transportation. In business, the food \& beverage sector annually shows a trend of a significant increase from 2014. The food \& beverage sector.
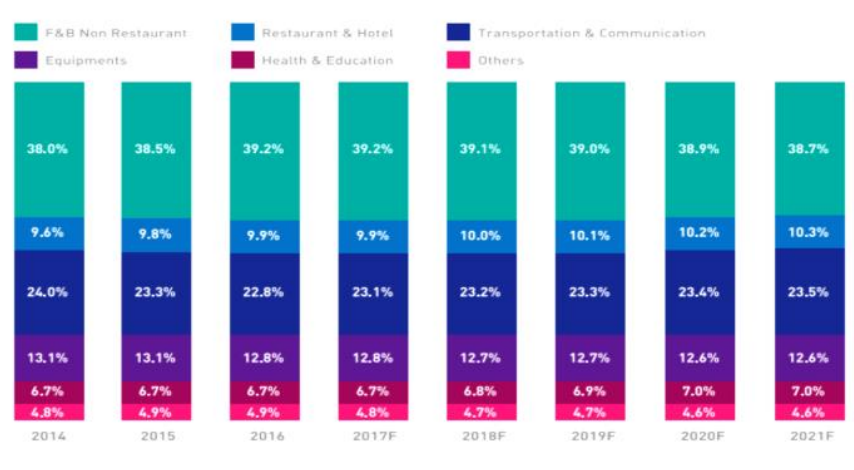

Figure 1 Mobile Payment consumption services in Indonesia

\section{B. MARKETING STRATEGY}

The communication channels used related to marketing, sales and raising awareness among customers regarding IDEAL platform products and services, in conveying the value proposition to the customer segment are as follows;

\section{Mobile Application}

According to Nielsen (2014), in Indonesia, at least six out of ten Indonesian consumers (61\%) stated that they use mobile phones most for online shopping. In addition, according to JakPat (2018), (49.01\%) respondents also like to use mobile payments because it is possible for them not to carry cash at any time. Apart from these two main reasons, survey results show that female respondents prefer to use mobile payments because there are many promotional offers and whereas men feel security is the most important issue.

\section{Digital Marketing}

Digital marketing effective and efficient marketing methods to be applied in Indonesia because the level of smartphone users and large internet users gives ease and flexibility to increase brand awareness of products or services through digital channels. Budgeting Digital marketing is also relatively more affordable compared to traditional marketing. Based on the gather's digital marketing spend report (2013) survey, small and medium businesses that implement digital marketing can save marketing budgets up to $40 \%$ 
(percent). And the results of performance are better than traditional marketing from the survey results showed $28 \%$ (percent) of small and medium businesses plan to move the allocation of traditional marketing to digital marketing. Based on Google's survey report (2013),

Measuring success will also be done through tools or software such as Google Analytics, tracking scripts, pixels, hoosts and tags to get more accurate results. Digital marketing can build public trust in companies through consumer services and social media. In building direct interaction with consumers the company can implement content marketing strategies, content marketing is one of the most effective ways for you business people to interact with consumers, according to a study by Aberdeen group the average conversion rate of a website that applies content marketing is $2.9 \%$ (percent).

\section{Event Marketing}

Based on the event marketing benchmarks and trends report (2019), most marketers believe that event marketing is the single most effective marketing channel to achieve business goals.

iDEAL platform offers the concept of the Nusantara Food Festival event with special food from each region and different distinctive flavors and will also be enlivened by national music, comedy, sharing sessions and friends MABAR to attract local people, communities, young women in enlivening the event. This will be able to arouse emotional customers and interact directly with prospective customers to introduce and socialize services so as to create brand loyalty.

\section{Direct Selling}

According to Kotler and Keller (2012), direct marketing is a direct relationship with individual target consumers to create direct responses and build long-term customer relationships. According to Hudson (2008), direct marketing is a marketing system that is fully controlled by marketers, develops products, promotes and distributes its products directly to end consumers by using several media options, and accepts orders directly from customers. According to Suyanto (2007), direct marketing is a marketing system that uses direct channels to reach consumers and deliver goods and services to consumers without going through marketing intermediaries to produce responses and or transactions that can be measured at a location. According to Fandy (2008), direct marketing is an interactive marketing system that utilizes one or several advertising media to cause measurable responses and or transactions in any location. According to Djaslim (2006), there are forms of direct marketing namely face to face selling, direct mail marketing, catalog marketing, telemarketing, kiosk marketing, and online media.

Based on the ANA / DMA response rate report (2018), the direct mail response rate is $4.9 \%$ for prospects in 2018. This is significantly higher than in 2017 and the highest since the report began in 2003. Direct mail still attracts a response rate that is higher than other direct digital marketing media. The response rate ranges from about 5\% (percent) to $9 \%$ (percent) times greater than email, paid search or social media. Email remains important or very important for the majority of $95 \%$ (percent) of marketers, but less than one in 10 (9\% Percent) thinks all emails are relevant to customers. More than five ( $42 \%$ percent) thought that the best.

\section{Community Marketing}

Marketing community marketing that must be the brand's attention is awareness and education. Community is the best channel for building customer engagement with customers. this has been done by "AIA Village" and "Kampung Indosat". Both of them do community marketing activities by plunging in one selected area to provide support to local residents for various community empowerment activities. This method is very effective in strengthening brand 
awareness and is a fast way to create brand loyalty which ultimately affects sales.

\section{PRICE SCHEME}

iDEAL platformusing a subscription pricing strategy. Subscription pricing is a business model where customers must pay a subscription to have access to application services from the IDEAL platform. In applying the pricing strategy set for IDEAL platform services, it can be analyzed starting from the ability of the market to pay, market conditions, competitors and input costs. It is important to consider the needs and target audience and the company's working capital budget. The subscription pricing used is promotional strategy, which is the consideration of offering a free trial for 14 working days after which the customer will be charged a transaction fee of $2 \%$ (percent) for the mobile platform while for the mPOS outlet application will be charged 150,000 / month.

\section{Business Model Canvas}

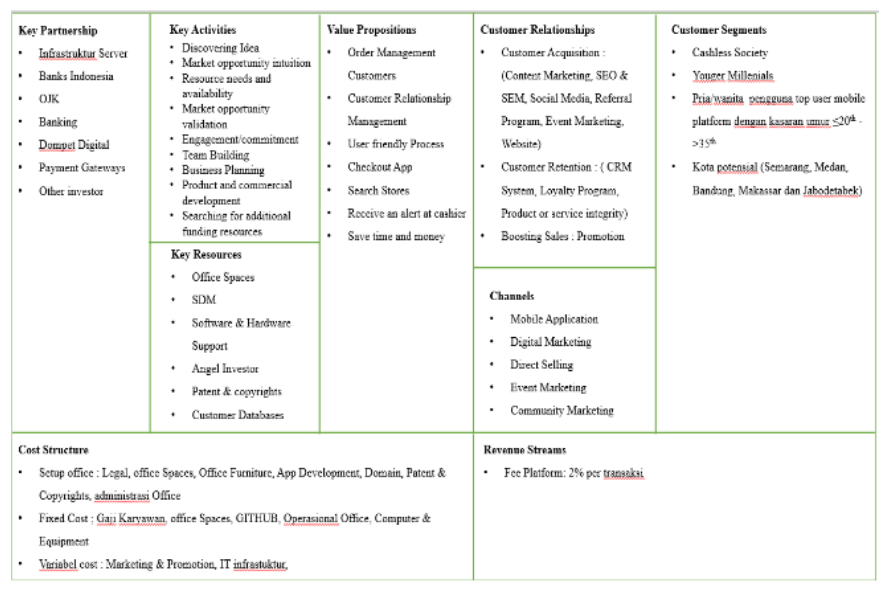

\section{FINANCIAL PLANNING}

\section{A. INCOME STATEMENT}

The projection of iDEAL platform income statement shows that the percentage of net profit increased significantly increased annually, from the calculation of profit and loss the investment plan iDEAL platform produced a fifth year net profit of Rp. 7,299,019,761 / year.
Table 1.3 Projection of Income Statement

\begin{tabular}{|c|c|c|c|c|c|}
\hline \multicolumn{6}{|c|}{ PROYEKSI LAPORAN LABA RUGI UNTUK 5 TAHUN } \\
\hline \multirow{2}{*}{ KETERANGAN } & \multicolumn{5}{|c|}{ TAHUN } \\
\hline & 1 & 2 & 3 & & 5 \\
\hline \multirow{2}{*}{$\begin{array}{l}\text { Pendapatan Ideal Payment per } \\
\text { transaksi } 2 \% \\
\text { Total pendapatan }\end{array}$} & 1.320 .000 .000 & 3.000 .000 .000 & 4.800 .000 .000 & 6.000 .000 .000 & 12.000 .000 .00 \\
\hline & 1.320 .000 .000 & 3.000 .000 .000 & 4.800 .000 .000 & 6.000 .000 .000 & 12.000 .000 .00 \\
\hline \multicolumn{6}{|l|}{ Beban Pokok Penjualan } \\
\hline Penyewaan Server & 16.349 .016 & 26.158 .426 & 41.853.481 & 66.965 .570 & 107.144.91 \\
\hline Penyewaan Domain & $\begin{array}{r}1.800 .000 \\
-55000\end{array}$ & 1.800 .000 & $\begin{array}{r}1.800 .000 \\
-5.000\end{array}$ & $\begin{array}{r}1.800 .000 \\
1.55000\end{array}$ & 1.800 .00 \\
\hline \multirow{2}{*}{$\begin{array}{l}\text { Penyewaan Github } \\
\text { Total Beban Pokok Penjualan }\end{array}$} & 11.550 .000 & 11.550 .000 & 11.550 .000 & 11.550 .000 & 11.550 .00 \\
\hline & 29.699 .016 & 39.508 .426 & 55.203 .481 & 80.315 .570 & 120.494 .91 \\
\hline Laba Kotor & 1.290 .300 .984 & 2.960 .491 .574 & 4.744 .796 .519 & 5.919 .684 .430 & 11.879 .505 .08 \\
\hline \multicolumn{6}{|l|}{ Beban Operasional } \\
\hline Biaya pengurusan usaha dan hakki & 11.000 .000 & & & & \\
\hline Biaya gaji karyawan dan direktur & 1.218 .000 .000 & 1.218 .000 .000 & 1.218 .000 .000 & 1.218 .000 .000 & 1.218 .000 .00 \\
\hline Biaya sewa kendara & 60.000 .000 & 60.000 .000 & 60.000 .000 & 60.000 .000 & 60.000 .00 \\
\hline Biaya sewa toko & 80.000 .000 & 80.000 .000 & 80.000 .000 & & 80.000 .00 \\
\hline Biaya kegiatan/event & & 120.000 .000 & 132.000 .000 & 145.200 .000 & 159.720 .00 \\
\hline Biaya pemasaran & 210.000 .000 & 231.000 .000 & 254.100 .000 & 279.510 .000 & 307.461 .00 \\
\hline Biaya perlengkapan kantor & 16.500 .000 & 18.150 .000 & 19.965 .000 & 21.961 .500 & 24.157 .65 \\
\hline Biaya peny. Inventaris kantor & 81.812 & 81.812 .500 & 81.812 .500 & 81.812 .500 & 81.812 .50 \\
\hline \multirow{2}{*}{$\begin{array}{l}\text { Biaya peny. Equipment } \\
\text { Total Beban Operasional }\end{array}$} & 4.475 .000 & & & & 4.475 .00 \\
\hline & 1.681 .787 .500 & 1.813 .437 .500 & 1.850 .352 .500 & 1.890 .959 .000 & 1.935 .626 .15 \\
\hline $\begin{array}{l}\text { Total Beban Operasional } \\
\text { Laba Operasional (EBIT) }\end{array}$ & $(391.486 .516)$ & 1.147 .054 .0 & 2.894 .444 .019 & 4.028 .725 .430 & 9.943 .878 .93 \\
\hline $\begin{array}{l}\text { Other Expence Income } \\
\text { Othe }\end{array}$ & & (511.258.878) & $(465.376 .671)$ & $(419.494 .464)$ & $(373.612 .25$ \\
\hline Profit before Tax & (391.486.516) & 635.795 .196 & 2.429 .067 .348 & 3.609 .230 .966 & 9.570 .266 .68 \\
\hline INCOME PPH PS 25 & & 344.116 .214 & 868.333 .197 & 1.208 .617 .620 & 2.983 .163 .67 \\
\hline Laba bersih & (391.486.516) & 291.678 .983 & 1.560 .734 .151 & 2.400 .613 .346 & 6.587 .103 .00 \\
\hline
\end{tabular}

PROYEKSI LAPORAN LABA RUGI UNTUK 5 TAHUN KETERANGAN TAHUN

\section{B. CASH FLOW STATEMENT}

From the results of the iDEAL cash flow statement that the operating cash flow capability can pay current liabilities based on a stable cash flow level with balanced income and expenses. Then the level of the company's ability to meet cash obligations in the future can pay current liabilities well without using other activity cash flow or additional loan capital.

Table 1.4 Projection of Cash Flow Statements

\begin{tabular}{|c|c|c|c|c|c|}
\hline \multicolumn{6}{|c|}{ PROYEKSI LAPORAN ARUS KAS UNTUK 5 TAHUN } \\
\hline KETERANGAN & & 3 & TAHUN & 4 & 5 \\
\hline Saldo kas awal periode & 549.093 .484 & 291.678 .983 & 1.560 .734 .151 & 2.400 .613 .346 & $\frac{5}{6.587 .103 .009}$ \\
\hline Arus has dari altivitas operasi & & & & & \\
\hline $\begin{array}{l}\text { Pendpatan Ideal Payment per transalks } 2 \% \\
\text { Biaya pengurusan washa dan hakki }\end{array}$ & $\begin{aligned} 1.320 .000 .000 \\
(11.000 .000\end{aligned}$ & 3.000 .000 .000 & 4.800 .000 .000 & 6.000 .000 .000 & 12.000 .000 .000 \\
\hline $\begin{array}{l}\text { Slayy pengumusan usaha dan ha } \\
\text { Biaya pemasaran }\end{array}$ & $(210.000 .0000)$ & $(231.000 .000)$ & $(254.100 .000)$ & $(279.510 .000)$ & $(307.461 .000)$ \\
\hline Biaya gaji karyawan & $(1.218 .000 .000)$ & $(1.218 .000 .0000$ & $(1.218 .000 .000)$ & $(1.218 .000 .000)$ & $\begin{array}{r}(1.218 .000 .000) \\
(60.000 .000)\end{array}$ \\
\hline 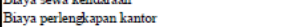 & $(16.500 .000)$ & $(18.150 .000)$ & $(19.965 .000)$ & $(21.961 .500)$ & $(24.157 .650)$ \\
\hline giatan/event & - & $(120.000 .000)$ & $(132.000 .000)$ & $(145.200 .000)$ & $(159.720 .000)$ \\
\hline Beban pajak & & & (866.333.197] & $(1.208 .617 .620)$ & $(2.983 .163 .673)$ \\
\hline Biaya penyusutan & $(86.287 .500)$ & $(86.287 .500)$ & $(86.287 .500)$ & $(86.287 .500$ & $(86.287 .500)$ \\
\hline Total arus kas bersih dari altivitas operasi & $(1.601 .787 .500)$ & $(2.077 .553 .714)$ & $(2.638 .685 .697)$ & $(3.019 .576 .620)$ & $(4.838 .789 .823)$ \\
\hline Anus kas dari aktivitas in & & & & & \\
\hline $\begin{array}{l}\text { Pembelian equipment } \\
\text { Pembelian inventanis kantor }\end{array}$ & $\begin{array}{l}(17.900 .000) \\
(327.250 .000)\end{array}$ & $\left.\begin{array}{r}(17.900 .000) \\
(327.250 .000)\end{array}\right)$ & $\left.\begin{array}{r}(17.900 .000) \\
(327.250 .000)\end{array}\right)$ & $\left.\begin{array}{c}(17.900 .000) \\
(327.250 .000)\end{array}\right)$ & $\left.\begin{array}{r}(17.900 .000) \\
(327.250 .000)\end{array}\right]$ \\
\hline Total arus kas bersih dari aldivitas investasi & $(345.150,000)$ & $(345.150 .000)$ & $(345.150 .000)$ & $(345.150 .000)$ & $(345.150 .000)$ \\
\hline $\begin{array}{l}\text { Arus kas dari altivitas pendanaan } \\
\text { Hutang Jangka Pendek }\end{array}$ & & & & & \\
\hline Hutang Usaha & 1.1499 .930 .000 & $(327.730 .050)$ & $(327.730 .050)$ & $(327.730 .050)$ & $(327.730 .050)$ \\
\hline Total arus kas bersih dari altivitas pendanaan & 2.090 .510 .0000 & & $(327.730 .050)$ & $(327.730 .050)$ & $(327.730 .050)$ \\
\hline Saldo Kas Alkhir & 2.012 .665 .984 & 868.975 .269 & 3.049.168.404 & 4.708 .156 .676 & 13.075.433.136 \\
\hline
\end{tabular}

C. FINANCIAL BALANCE REPORT Overall, the assets and equity increased significantly by $\mathrm{Rp}$. $13,750,235,697$ in year 5 as 
illustrated in the following table;

Table 1.5 Projected Balance Sheet Statements

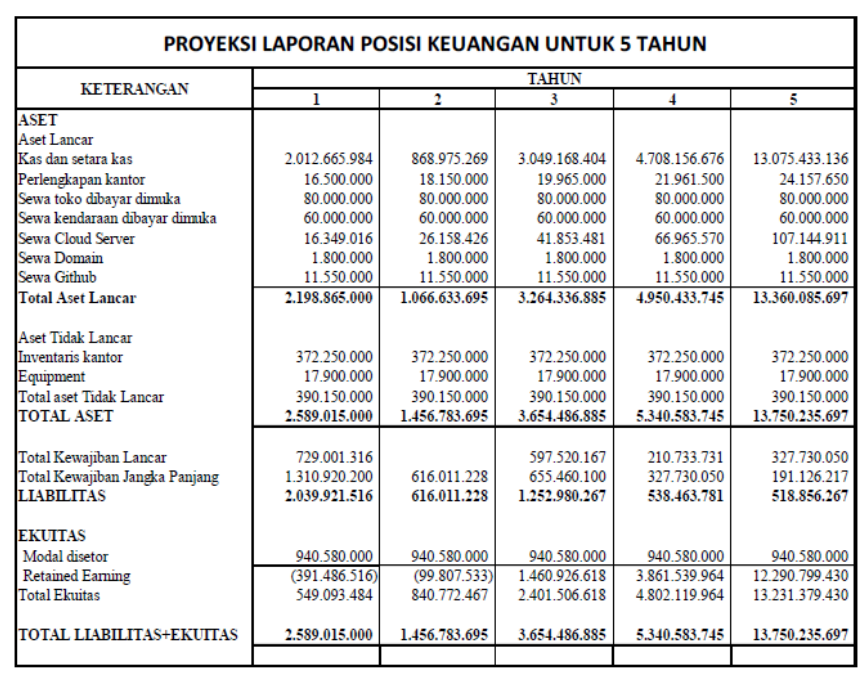

\section{BUSINESS WORTHED}

A project can be said to be financially feasible or not can be known from the investment criteria. (Husnan and Suwarsono, 1997). To conduct business feasibility financially the criteria include the following;

\section{A. FINANCIAL ANALYSIS}

Based on cash flow data (cash flow) with an interest rate of $12 \%$ and $18 \%$. Then it can be seen the results of the business feasibility value by using investment valuation criteria namely NPV (net present value), IRR (internal rate of return) and PP (payback period), along with the results of the financial feasibility analysis of iDeal Platform business;

Table 1.6 Investment Valuation Analysis

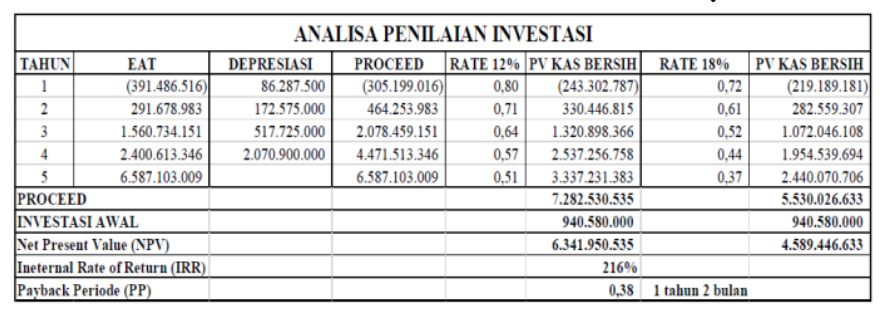

From the results of the analysis showed a positive NPV with a NPV value greater than $>0$ ie Rp. $6,341,950,535$, this business investment activity is feasible to be accepted, with the rate of business return on investment capital invested by IRR of $216 \%$ greater than the discount factor, this business can be run and has the potential to provide a profit with a payback period of payback period of 1 year 2 month.

\section{B. PROFITABILITY RATIO}

One of the ratios used by the iDEAL platform is to determine the ability of the company to get profits from earnings (earnings) related to sales, assets and equity in a certain period using the profitability ratio scenario. Following are the results of the profitability ratio scenario;

Table 1.7 Analysis of Profitability Ratios

\begin{tabular}{|l|r|r|r|r|r|}
\hline \multicolumn{7}{|c|}{ Analisis Rasio Profitibilitas } \\
\hline & 1 & 2 & 3 & 4 & 5 \\
\hline Gross Profit Margin & $98 \%$ & $99 \%$ & $99 \%$ & $99 \%$ & $99 \%$ \\
\hline Net Profit Margin & $-30 \%$ & $10 \%$ & $33 \%$ & $40 \%$ & $55 \%$ \\
\hline Return on Assets & $-15 \%$ & $79 \%$ & $79 \%$ & $75 \%$ & $72 \%$ \\
\hline Return on Investment & $-15 \%$ & $20 \%$ & $43 \%$ & $45 \%$ & $48 \%$ \\
\hline
\end{tabular}

\section{RECOMMENDATION}

From the results of the iDEAL platform's business plan there are a number of points to consider, as follows;

1. The development of the Ideal payment platform application is carried out within a period of 6 (six) months with a team requirement of 7 people consisting of (Business Analysis, Web development, UI / UX, Mobile Development, User Acceptance Testing, CEO and CTO).

2. During the development process to reduce the budget, it is better for the office to be done in coworking space or in their respective homes where to further facilitate the flexibility of the developers, then in 1 week there are 2 meetings 
to discuss and monitor the development of the application development.

3. The amount of deposit and registration funds from Bank Indonesia, an alternative iDEAL platform is to collaborate with third parties such as digital wallet and banking service providers in the country, hoping that in the future iDEAL platform can have its own payment gateways.

4. During the development period to fulfill the application development process, the management tried to find funding through angel investors from various pitching proposals held in the country with the MVP (Minimum Availaible Product) maturation process from the iDEAL platform.

5. During the development of iDEAL the platform uses the scrum development method to accelerate application development and makes it easier to review and execute when there are changes or additions without having to go through a long process.

6. Server tools supporting the iDEAL platform is the cloud computing service (Google Cloud Platform), for managing data storage, the Google cloud platform with attractive offers including fast speed, security, reliable infrastructure, flexibility and analytic report services.

7. Development of the organizational structure Ideal payment platform uses moderation to cut bureaucracy and increase organizational productivity and innovation, by applying cultural values that have integrity, innovative, autonomy, and collaborative.

8. The main strategy implemented by the iDEAL platform is to focus on user experience, which can provide added value for ease of use and the continued development of the iDEAL Platform, so that the application offered as a tool is needed by customers in food \& beverage spending.

9. Development of the iDEAL advanced platform must be implemented by the API system to be integrated with the online cashier system that already exists in the country, so that the use of the iDEAL mobile platform can be more widespread.

10. The development of the iDEAL advanced platform must also be used as a QRIS payment system and transfer funds.

\section{REFERENCES}

[1]. Original DK, etc (2017). The Global Findex Database. Measuring Financial Inclusion and the Fintech Revolution.

[2]. Andi Tjiptono, Fandy. 2008. Marketing Strategy. Yogyakarta: Andi Publisher.

[3]. Bain \& company, (2001). The Economics of ELoyalty. Harvard Business Review.

[4]. Bambang Pramono, Tri Yanuarti Flatback DP, Yosefin Tyas Emmy DK (2006). The Impact of Non-cash Payments on the Economy and Monetary Policy. Bank Indonesia Working Paper. Journals Beaumont, PB (1993). Human Resource Management: Key, Concept and Skill. London: Sage Publication Ltd.

[5]. Business Insider, (2 014). Alipay Overtakes Paypal As The Largest Mobile Payments Platform In the Word. Accessed July 31, 2019https://www.businessinsider.com/alip ayovertakes-paypal-as-the-largest- mobilepayments-platform-in-the-world- 2014-2?IR=T

[6]. Bloomberg, (2018). Quicktake: My Phone Is My Wallet. Accessed July 31, 2019.https://www.bloomberg.com/quickta ke/mobile-payments CX network, (2018). Striving for omnichannel excellence. Being obsessed with your customer in an omnichannel age. survey

[7]. Capps III, CJ, \& Glissmeyer, MD (2012). Extending The Competitive Profile Matrix. a journal

[8]. Chan, S., (2003). Relationship Marketing (Marketing Innovations That Make Knees Customers). Jakarta, Indonesia: PT. Gramedia Main Library. 
[9]. David, FR, (2011). Strategic management: Concepts and cases (13th ed.). Upper Saddle River, NJ: Prentice Hall.

[10]. Davis, FD (1989). Perceived Usefulness, Perceived Ease of Use, and User Acceptance of Information Technology. MIS Quarterly, 13, pp 319-340

[11]. Databooks, (2017). Mobile Users and Social Media Penetration. Survey. Accessed August 31,

[12]. 2019https://databoks.katadata.co.id/datap ublish/2017/08/29/pengguna-ponsel- indonesiamain-142-from-population

[13]. DailySocial, (2018). Fintech Report 2018.

[14]. FT Confidential Research, (2018). Indonesia Mobile Payment Set For Cross Platform Boom. Mobile Payment. Survey. Accessed on August 21, 2019https://app.ft.com/content/e9a50f6c037a-11e9-99df-6183d3002ee1

[15]. Fred R. David (2011). Strategic Management; Concepts and Cases. Thirteenth Edition.

[16]. Google (2019). 2019 Year in Search Indonesia.

[17]. Insights for Brands.

[18]. Hestin M, etc (2014). Analysis of Types of Electronic Payment Systems in E- commerce Transactions in Indonesia. National Seminar on Information and Communication Technology. Yogjakarta

[19]. Holmes, A., Byrne, A. and Rowley, J. (2014) 'Mobile shopping behavior: insights into attitudes, shopping process involvement and location', International Journal of Retail \& Distribution Management. Vol. 42 No. 1, pp. 25-39.

[20]. Hudson, Simon, (2008). Tourism and Hospitality Marketing: A Global Perspective. London: SAGE Publications Ltd.

[21]. IPrice, App Annie, (2019). Top 10 most popular e-Wallet applications in Indonesia since 20172019. Accessed on August 18, 2019https:/iprice.co.id/trend/insights/e- walletterbaik-di-indonesia/
[22]. JakPat, (2018). Digital Wallet Promotional Program. Survey Report

[23]. JakPat, (2018). Mobile Payment In Indonesia.

[24]. Jungsu K., GH Chung, (2017). Implementing innovations within organizations: a systematic review and research agenda.

[25]. Johnson, G., Scholes, K., \& Whittington, R. (2008). Exploring corporate strategy: text \& cases. Pearson Education.

[26]. Kotler, P., Armstrong, G., (1997), Fundamentals of Marketing, Principles of Marketing $7 \mathrm{e}$, Indonesian Edition, Volume 1, translated by Drs. Alexander Sindoro, Prenhallindo, Jakarta.

[27]. KMPG (2014). Retail Industry Outlook Survey. Research

[28]. Kotler, Philip and Keller, Kevin Lan. (2012). Marketing Management. Pearson: Marketing Management. Jakarta: Erlangga.

[29]. Kotter, J., Heskett (1992). Organizational Behavior. Sixth Edition. New York: Prentice Hall, Inc

[30]. Kravertz, (1988). The Human Resource Revolution: Implementing Progressive Management Practices for Bottom Line Success.

[31]. Moch. Afif, Berto Mulia, (2019). Map Analysis of Mobile Payment Industry Competitors in Indonesia. Journals

[32]. Murphy, J, A. (2001). The Lifebet The Definitive Guide to Managing Customer Retention. England: John Wiley \& Sons Ltd.

[33]. Mastercard, (2013). Smartphone Shopping Trend Sweeps Asia / Pacific Region: Mastercard Online Shopping. Survey. Accessed on August 3, 2019.https://www1.mastercard.com/conte nt/intelligence/en/research/pressrelease/2013/smartphone-shopping-trendsweeps-asia-pacific-region-- mastercard.html

[34]. Nielsen (2019). Understanding Indonesia's Online Food Delivery Market. Research

[35]. Nielsen (2018). Nielsen Food Trip Study. Survey 
[36]. Osterwalder, A., \& Pigneur, Y. (2010). Business Model Generation. New Jersey: John Wiley \& Sons, Inc.

[37]. Osterwalder, A., Pigneur, Y., Bernarda, G., \& Smith, A. (2014). Value PropostionDesign. Hoboken, NJ: John Wiley \& Sons, Inc.

[38]. Porter, ME (1979). The structure within industries and companies' performance. Review of Economics and Statistics, 61 (2), 214-227.

[39]. Patrick (2014). Ogilvy Cannes Study: Behold the power of word of mouth. Study case

[40]. PwC Indonesia, (2018). Digital Banking in Indonesia 2018. Digital Strategy as a Corporate Strategy. Survey. Accessed July 29,

[41]. 2019https://www.pwc.com/en/en/mediacentre/press-release/2018/indonesian/ sacrificedigital-indonesia-surveys- 2018.html

[42]. Research and Market, (2019). Indonesia mobile and payment market Opportunities. Databook series.

[43]. RedSeer, (2019), Indonesia Fintech Report 2019.

[44]. Based research; the Jakarta Globe.

[45]. Suyanto, M. (2007). Indonesia's Top Brand Marketing Strategy. Jogjakarta:

[46]. Schwaber, K., Sutherland, J., 2011, The Definitive Guide to Scrum: The Rules of the Game.

[47]. Thompson, Jr., Arthur, A., Peteraf, MA, Gamble, J, E., \& Strickland, A, J. (2012). Crafting and Executing Strategy: Concepts and Cases. New York : The McGraw-Hill Companies, Inc.

[48]. Untoro, R.Aria Trenggana, Komala Dewi (2013).

[49]. Product and Risk Mapping. Journals University of Concordia (2011). Research from Concordia Business Professors: Giving Workers More Autonomy Pays Huge Divident

[50]. Zimmerer, T., Scarborough, N, M., \& Wilson, D. (2008). Essentials of entrepreneurship.

[51]. Gather's Survey, (2013). Digital marketing spend report. Survey. Accessed on 8 September 2019.https://www.gartner.com/technology/rese arch/digital-marketing/digitalmarketingspend-report.jsp

[52]. 2019.https://www.mediapost.com/publications/ a rticle/201157/shoppers-prefer-personalizedbrick-mortar-vs-on.html?print\#axzz2VYmFam

[53]. Synqera, (2013).Personalized Brick \& Mortar vs. Online Prefer Shoppers. Study case. Accessed November 18

\section{Cite this article as :}

Hengki Sulaiman, "iDeal Mobile Food and Beverage Platform", International Journal of Scientific Research in Science and Technology (IJSRST), Online ISSN : 2395-602X, Print ISSN : 2395-6011, Volume 8 Issue 3, pp. 836-846, May-June 2021. Available at doi : https://doi.org/10.32628/IJSRST2183102 Journal URL : https://ijsrst.com/IJSRST2183102 